\title{
Influence of Oceanographic Parameters on the Seasonal Potential Fishing Grounds of Rastrelliger kanagurta using Maximum Entropy Models and Remotely Sensed Data
}

(Pengaruh Parameter Oseanografi terhadap Kawasan Potensi Musiman Penangkapan Ikan Rastrelliger kanagurta menggunakan Model Entropi Maksimum dan Data Satelit)

\author{
S.M. YUSOP \& M.A. MUSTAPHA*
}

\begin{abstract}
Understanding of the spatial distribution of fish habitats is crucial in order to achieve optimum fishing and to increase efficiency of marine resource management. In this study, seasonal potential suitability habitat model for Rastrelliger kanagurta off the east coast of Peninsular Malaysia was derived using maximum entropy (MaxEnt) by utilizing fishing locations and environmental parameters from remotely sensed sea surface temperature (SST) and chl-a concentration (chl-a) data. The influence of environmental parameters on the formation of the potential fishing zones was also determined. The results showed that all the seasonal models performed significantly better than random with AUC $>0.80$, which indicated that the constructed models were applicable with 'good' to 'excellent' predictive accuracy. The model also showed that chl-a influenced $\mathrm{R}$. kanagurta's potential fishing ground during northeast and intermediate monsoon of October. Meanwhile, SST contributed more in defining the potential fishing grounds during southwest and intermediate monsoon period of April. The seasonal and spatial extents of potential fishing grounds were largely explained by chl-a (0.32-0.42 $\mathrm{mg} / \mathrm{m}^{3}$ during northeast, $0.27-0.66 \mathrm{mg} / \mathrm{m}^{3}$ in April, $0.21-0.30 \mathrm{mg} / \mathrm{m}^{3}$ during southwest monsoon and $0.22-0.39 \mathrm{mg} / \mathrm{m}^{3}$ in October) and SST (29.05-29.94 $\mathrm{C}$ during northeast monsoon, 31.18-31.47 ${ }^{\circ} \mathrm{C}$ in April, 31.17-31.48 $\mathrm{C}$ during southwest monsoon and $30.34-31.11^{\circ} \mathrm{C}$ in October). This indicated that seasonal changes in oceanographic parameters influenced spatial distribution of fish. The results also demonstrated the applicability and potential of MaxEnt in determination of potential fishing grounds and describing the influence of oceanographic factors on the formation of the area.
\end{abstract}

Keywords: chl-a; habitat suitability map (HSM); MaxEnt; seasonal distribution; SST

ABSTRAK

Memahami taburan reruang habitat ikan adalah penting untuk mencapai penangkapan optimum dan meningkatkan kecekapan pengurusan sumber laut. Dalam kajian ini, model potensi kesesuaian habitat musiman bagi Rastrelliger kanagurta di pantai timur Semenanjung Malaysia diperoleh melalui model entropi maksimum (MaxEnt) dengan menggunakan lokasi penangkapan dan parameter persekitaran suhu permukaan laut (SPL) dan kepekatan klorofil-a (chl-a) daripada data penderiaan jauh. Pengaruh parameter persekitaran terhadap pembentukan zon potensi perikanan juga ditentukan. Hasil model MaxEnt menunjukkan bahawa semua model musiman adalah jauh lebih baik daripada rawak pada AUC> 0.80 yang menunjukkan bahawa model yang dibina sesuai dengan ketepatan ramalan 'baik' ke 'cemerlang'. Keputusan daripada model ini juga menunjukkan bahawa kepekatan chl-a lebih mempengaruhi kawasan potensi perikanan R. kanagurta semasa monsun timur laut dan monsun peralihan pada bulan Oktober. Sementara itu, SPL mempengaruhi penentuan kawasan potensi perikanan semasa musim monsun barat daya dan monsun peralihan pada bulan April. Sebahagian besar kawasan potensi perikanan diasosiasikan dengan chl-a $\left(0.32-0.42 \mathrm{mg} / \mathrm{m}^{3} \mathrm{semasa}\right.$ monsun timur laut, 0.27-0.66 mg/m $\mathrm{m}^{3}$ pada bulan April, $0.21-0.30 \mathrm{mg} / \mathrm{m}^{3}$ semasa monsun barat daya dan 0.22-0.39 $\mathrm{mg} / \mathrm{m}^{3}$ pada bulan Oktober) dan SPL (29.05-29.94 $\mathrm{C}$ semasa monsun timur laut, 31 18-31.47 $\mathrm{C}^{\circ}$ pada bulan April, 31.17-31.48 $\mathrm{C}$ semasa monsun barat daya dan 30.34-31.11 ${ }^{\circ} \mathrm{C}$ pada bulan Oktober). Hal ini menunjukkan bahawa perubahan musiman bagi parameter oseanografi mempengaruhi taburan reruang ikan. Keputusan kajian juga menunjukkan kebolehan dan potensi MaxEnt dalam penentuan kawasan potensi perikanan dan menjelaskan pengaruh faktor oseanografi terhadap pembentukan kawasan tersebut.

Kata kunci: Klorofil-a; MaxEnt; peta kesesuaian habitat; SPL; taburan bermusim

\section{INTRODUCTION}

Marine fisheries sector in Malaysia has been playing an important role not only as a major animal protein source but also as source of employment and foreign exchange. The genus Rastrelliger, the Indian mackerel or Rastrelliger kanagurta is one of the most abundant 
and commercially important marine resource aggregates widely across the northwest and east Peninsular Malaysia, Sabah and Sarawak. As this species feeds on varied diet composition such as phytoplankton and zooplanktons in its juvenile stage while adult mackerel preys primarily on macroplankton such as larval shrimps, it has been classified as a planktonivore/omnivore. This species is known by its ability as a fast swimmer and therefore highly migratory and often found in large schools in shallow coastal waters with depth range of 20-90 m (Vivekanandan et al. 2009).

The size and location of fishing grounds of $R$. kanagurta are largely influenced by oceanographic conditions, often resulting in seasonal fluctuations in landings (Krishnakumar et al. 2008; Syah et al. 2016). The occurrence and abundance of the species in the east coast of Peninsular Malaysia have been associated with chlorophyll- $a$ (chl- $a$ ) concentration and sea surface temperature (SST) (Mustapha et al. 2014). Chl- $a$ and SST have been shown to be important parameters and commonly used to determine potential fishing for albacore tuna in the northwestern North Pacific (Zainuddin \& Saitoh 2004). Meanwhile, Lanz et al. (2009) analyzed the distribution of small pelagic fishes such as Pacific sardine, thread herring, northern anchovy and Pacific mackerel in the Gulf of California in relation to SST and chl- $a$ concentration. SST plays a role in stimulating distribution patterns by influencing biological richness of an oceanic area and chl- $a$ concentration is often linked with primary production level which indicates the fish production in the area (Solanki et al. 2001). Other climatological factors such as wind and rainfall also influences oceanographic conditions and have a direct impact on fishing pressure and catch (Rijnsdorp et al. 2009). Therefore, understanding the relationship between these factors and abundance of species is essential for effective fisheries management (Syah et al. 2016).

Various studies have been conducted which showed the application of remote sensing data to understand the physical and biological processes which governs potential fishing grounds. Moderate Resolution Imaging Spectroradiometer (MODIS) has successfully provided reliable global ocean coverage of SST and chl- $a$ concentration at relatively high spatial and temporal resolution for determining the potential fishing grounds of $R$. kanagurta in the archipelagic waters of Spermonde (Nurdin et al. 2015). Meanwhile, Nammalwar et al. (2013) has demonstrated the ability of Indian Remote Sensing Satellite (IRS-P4) Ocean Color Monitor (OCM) in deriving chl- $a$ data and National Oceanic and Admiral Administration-Advanced Very High Resolution Radiometer (NOAA-AVHRR) for SST data in detection of some pelagic species in Indian waters.

Integration of habitat suitability modeling has also been widely used to analyze the distribution of fish species in relation to environmental predictors (Alabia et al. 2015; Manderson et al. 2011). Most models use presence-only data (consists of a sample of locations with known presences) however, traditionally has also been conducted with presence-absence data $(\mathrm{Gu} \&$
Swihart 2004; Mackenzie et al. 2002). Maximum Entropy (MaxEnt) which is a recent modelling technique based on MaxEnt algorithm (Phillips \& Dudik 2008; Phillips et al. 2006) combines both presence-only data (species occurrence dataset) and environmental parameters to determine the probability of suitable habitat for a species at each pixel within the geographic bound (Phillips et al. 2006). Several studies have pointed out that MaxEnt modeling which has been successfully used in a broad range of marine and terrestrial applications has also been proven to be among the best performing methods for presence-only data compared to the results of presenceabsence methods such as Generalized Linear Model (GLM), Generalized Additive Model (GAM), Bioclimatic Model (BIOCLIM) and Genetic Algorithm for Rule-set Production (GARP) distribution models (Alabia et al. 2015; Duan et al. 2014; Elith et al. 2006; Hernandez et al. 2006; Syah et al. 2016; Tobeña et al. 2016). Due to the importance of identifying suitable fishing habitats, this study derived potential suitability habitat model for R. kanagurta in the South China Sea (SCS) using MaxEnt with the objectives to predict distribution using environmental variables and to determine the influence of the environmental variables on distribution.

\section{MATERIALS AND METHODS}

\section{STUDY AREA}

The study area covers the Exclusive Economic Zone (EEZ) of East Malaysia $\left(102^{\circ} \mathrm{E}-108^{\circ} \mathrm{E}\right.$ and $\left.1^{\circ} \mathrm{N}-8^{\circ} \mathrm{N}\right)$ (Figure 1). It is a shallow area with an average depth of $60-70 \mathrm{~m}$. The climate over this area is characterized by SCS monsoon (Akhir \& Chuen 2011). The general characteristics of the climate in Malaysia are uniform temperature, high humidity with light and variable wind. The wind demonstrates uniform periodic changes in flow patterns which distinguishes the four seasons; northeast monsoon (November-March) which characterizes the wet season, southwest monsoon (May-September) the relatively dry season and two short intermediate monsoons (April and October) which are characterized by heavy rainfall (MMD 2017).

\section{RASTRELLIGER KANAGURTA OCCURRENCE DATA}

The $R$. kanagurta fishing data were provided by the Southeast Asian Fisheries Development Center (SEAFDEC). The dataset contained information of daily fishing locations in 2009, covering the fishing areas in the EEZ. A total of 2365 fishing occurrences were compiled into monthly databases and were arranged according to the four seasons; 499 during northeast monsoon, 1483 during southwest monsoon and 277 and 156, respectively, during intermediate monsoons (April and October). All the fishing data were used (as it is) to indicate location of presence data. Presence data is used for determination of fish distribution using MaxEnt. 


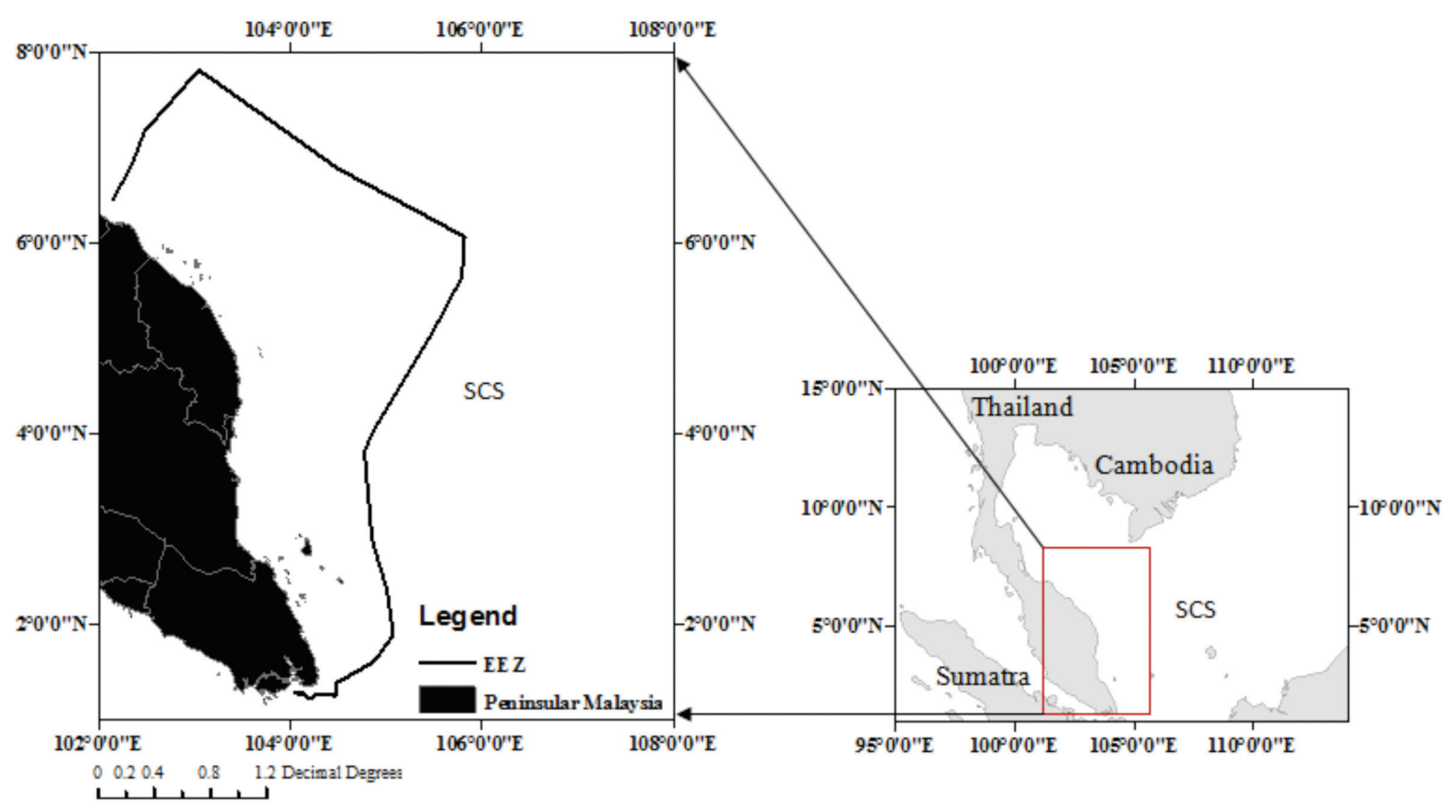

FIGURE 1. Geographic location of fishing grounds for R. kanagurta in the EEZ off east coast of Peninsular Malaysia

\section{ENVIRONMENTAL DATA}

Monthly SST and chl- $a$ values of 2009, at $4 \mathrm{~km}$ spatial resolutions were derived from MODIS Aqua satellite imageries (Table 1). The images were downloaded from the ocean color website (http://oceancolor.gsfc.nasa.gov/). Level 3 (L3) monthly data was used as daily images of the study area have limited data coverage. Monthly composites from daily data also have limited coverage that corresponds to the fishing position. The L3 data are re-sampled and often averaged spatially and temporally to produce single estimates of SST and chl- $a$ distribution for each grid location in order to achieve the highest possible accuracy and precision (Chassot et al. 2011). These data were extracted and processed using SeaWiFS Data Analysis System (SEADAS) package version 6.1 (O'Reilly et al. 1998) and were subset to the extent of 102-108 E and 1-8 N using ERDAS Imagine version 10.0 software. The environmental data were set to the same extent, at 0.04 arc-min resolution and converted to ASCII format using ArcGIS (Tobeña et al. 2016).

Monthly ocean surface wind speed data and direction were derived from Quick Scatterometer (QuickSCAT) satellite imageries at $25 \mathrm{~km}$ spatial resolutions and were downloaded from the NOAA OceanWatch website (http://pifsc-oceanwatch.irc.noaa.gov/erddap/griddap/
OceanWatch_qscat_wind_monthly.html). The data were processed using ArcGIS to determine the influence of wind on sea surface environment. Meanwhile, daily rainfall data were obtained from the Malaysian Meteorology Department and Drainage and Irrigation Department and compiled into monthly data of January, April, June and October of 2009 which represents northeast, southwest and the two intermediate monsoons.

Correlations between the environmental data of SST and chl-a were analyzed using Pearson correlation coefficients. The seasonal environmental data indicated weak correlation at $r<0.3$, excluding intermediate monsoon of October which showed moderate correlation at $r<0.5$. The results indicated low correlations between the parameters and are suitable to build the models.

\section{MAXENT MODEL CONSTRUCTION}

The northeast, southwest and intermediate monsoons monthly-fish occurences data in 2009 and its associated environmental variables were used to derive models in MaxEnt. The models generated were constructed using default value of 1 for regulation multiplier to reduce over-fitting during model training. Background points or randomly sampled points from the geographical space

TABLE 1. Environmental data used to generate the species distribution model in MaxEnt

\begin{tabular}{ccccc}
\hline $\begin{array}{c}\text { Environmental } \\
\text { variables }\end{array}$ & $\begin{array}{c}\text { Temporal } \\
\text { resolution }\end{array}$ & $\begin{array}{c}\text { Spatial } \\
\text { resolution }\end{array}$ & Units & Data source \\
\hline $\begin{array}{c}\text { Sea surface } \\
\text { temperature (SST) }\end{array}$ & Monthly & $4 \mathrm{~km}$ & ${ }^{\circ} \mathrm{C}$ & MODIS \\
Chlorophyll-a (Chl-a) & Monthly & $4 \mathrm{~km}$ & $\mathrm{mg} / \mathrm{m}^{3}$ & MODIS \\
\hline
\end{tabular}


were treated as pseudo-absences and were set to 10000 , maximum iterations to 500 and feature class selection was set to automatic. The presence data were randomly split into $70 \%$ training and $30 \%$ test points for each of the regional models (Alabia et al. 2015). In this study, 4 datasets were used to represent the training and test points according to monsoons, respectively, northeast (315 and 134), southwest (1039 and 444), intermediate monsoons of April (194 and 83) and October (110 and 46). In addition, 'fade by clamping' option was used to control extrapolation beyond the range of training dataset (Muthoni 2010). Meanwhile, the output values were produced using logistic format because the format can be interpreted easier and accurately especially when projected into GIS as the scores range from 0-1 (Philips \& Dudik 2008; Phillips et al. 2006).

\section{MODEL EVALUATION}

The approach used for model evaluation in this study was the Receiver-Operating Characteristic (ROC)-Area under the Curve (AUC) in MaxEnt. Area under ROC (AUC) demonstrates the predictive accuracy of distribution models (Elith et al. 2006; Phillips et al. 2006; Reddy et al. 2015). The AUC's are developed from ROC plots to measure the ability of the model to distinguish between environmental samples and known presences. In order to examine the relative contribution of each individual environmental predictor, MaxEnt generated a heuristic percentage contribution of each variable and it was estimated based on the increase in the model gain, which added to the contribution of the environmental variables to its corresponding model feature. The generated results were evaluated based on the output of percent contribution, permutation importance and jackknife procedure (Muthoni 2010). In addition, relationship between model-derived environmental variable with presence probability at 0.5 fixed threshold was determined.

\section{RESULTS}

\section{FISHING FREQUENCY IN RELATION TO ENVIRONMENTAL FACTORS}

Fishing frequency in relation to environmental parameters in the EEZ area in 2009 during northeast, southwest and intermediate monsoons of April and October are shown in Figure 2. Classification of the data resulted in the non-normal distribution curve observed in the certain
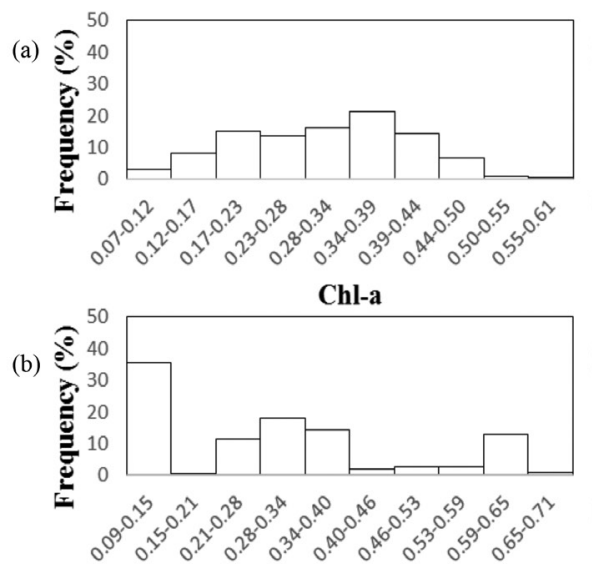

Chl-a

(c)

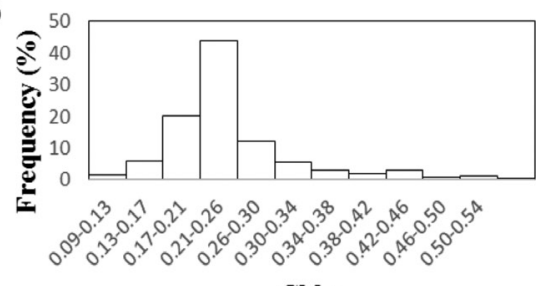

(d)

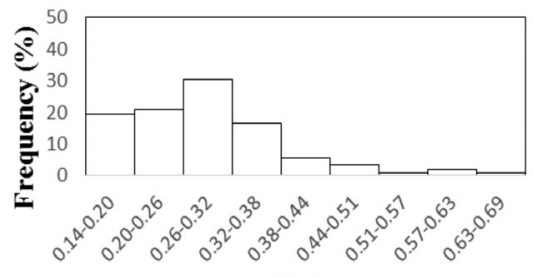

Chl-a

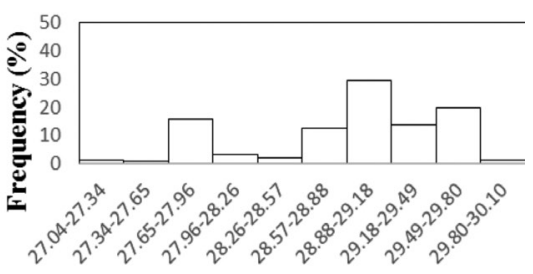

SST
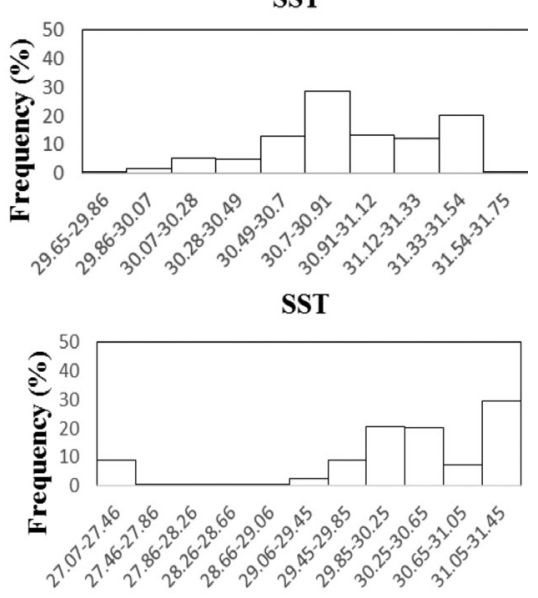

SST

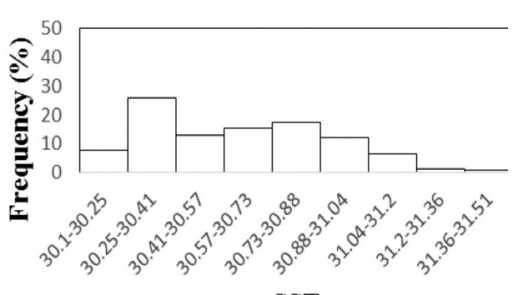

SST

FIGURE 2. Fishing frequency in relation to chl $-a\left(\mathrm{mg} \mathrm{m}^{-3}\right)$ (left panel) and SST $\left({ }^{\circ} \mathrm{C}\right)$ (right panel) during (a) northeast monsoon, (b) April, (c) southwest monsoon and (d) October of 2009 
monsoon aside from lesser availability of data. During northeast monsoon, highest fishing activities occurred at chl- $a$ range of $0.34-0.39 \mathrm{mg} / \mathrm{m}^{3}$ and SST at $28.88-29.18^{\circ} \mathrm{C}$ (Figure 2(a)), chl- $a$ between $0.09-0.15 \mathrm{mg} / \mathrm{m}^{3}$ and SST between $30.70-30.91{ }^{\circ} \mathrm{C}$ during intermediate monsoon of April (Figure 2(b)), chl- $a$ concentration of $0.21-0.26 \mathrm{mg} / \mathrm{m}^{3}$ while SST at $31.05-31.45^{\circ} \mathrm{C}$ (Figure 2(c)) during southwest monsoon and chl- $a$ of $0.26-0.32 \mathrm{mg} / \mathrm{m}^{3}$ and SST between $30.25-30.41^{\circ} \mathrm{C}$ during intermediate monsoon in October (Figure 2(d)).

\section{MODEL PERFORMANCE AND FACTORS INFLUENCING} R. KANAGURTA'S POTENTIAL DISTRIBUTION GROUNDS

The predictive reliability of the models was evaluated using the AUC statistics. Models with test-AUC values of AUC $\geq 0.8$ has good to excellent predictive performance, $0.70 \leq$ AUC $<0.80$ has moderate performance and AUC $<$ 0.7 has poor predictive performance (Duan et al. 2014). All the regional models performed significantly better than random with AUC $>0.80$ (Table 2), ranged from 0.82-0.92. These AUC values indicated that the constructed models were applicable for predicting the habitat distribution of $R$. kanagurta with 'good' to 'excellent' predictive accuracy. The statistics derived from the models also showed higher confidence on the estimate of AUC, which is shown from the similar standard deviation (SD) of AUC values. The habitat suitability maps for $R$. kanagurta for 2009 are shown in Figure 3. High suitable habitats for $R$. kanagurta were predicted along the coastal area with wider distribution towards offshore during northeast and intermediate monsoon of October. Meanwhile, during intermediate monsoon of April and southwest monsoon, suitable habitats for R. kanagurta were also observed along the coastal area, but with lesser distribution. However, suitable habitats increased towards offshore area in the northern waters.

Contribution of the variables influencing the potential habitat distribution was determined using percent contribution, permutation importance and jackknife test. It was observed that, when used alone, chl- $a$ contributed the most to the model gain during northeast and intermediate monsoon of October at 0.69 and 0.81 , respectively, and $71 \%$ and $73.4 \%$ relative contribution to the predicted distribution of $R$. kanagurta, respectively (Figure 4(a) and $4(d)$ ). Additionally, the permutation importance of chl- $a$ for the particular monsoons was recorded at $89.4 \%$ and $62.2 \%$, respectively. This indicated that the models have huge dependency on the variable because it contained necessary information for the model since it exhibited modest reductions in training gain when it was removed from the model. The results also showed that SST contributed less to the model development during those particular monsoons. However, SST was the most influential environmental variable in determining habitat suitability during intermediate monsoon of April and southwest monsoon and recorded the highest training gain; 1.31 and 1.19 when used alone and $60.1 \%$ and $53.6 \%$ relative contribution to the predicted distribution of $R$. kanagurta respectively. Chl- $a$ recorded less contribution during the particular monsoons (Figure 4(b) and 4(c)). Based on permutation importance, SST was the most significant variable in April at $66.8 \%$. However, during southwest monsoon, chl- $a$ was the most influential variable (68\%). SST also indicated reduction in training gain when removed from the model with the most in southwest monsoon.

Response curves showed the relationships between presence probability of $R$. kanagurta at 0.5 fixed threshold and seasonal environmental variables (Figure 5). During northeast monsoon, the probability of $R$. kanagurta distribution was observed at SST and chl- $a$ range of $29.05-29.94^{\circ} \mathrm{C}$ and $0.32-0.42 \mathrm{mg} / \mathrm{m}^{3}, 31.29-31.47^{\circ} \mathrm{C}$ and $0.27-0.66 \mathrm{mg} / \mathrm{m}^{3}$ during intermediate monsoon of April, $31.17-31.48^{\circ} \mathrm{C}$ and $0.21-0.30 \mathrm{mg} / \mathrm{m}^{3}$ during southwest monsoon and $30.34-31.11^{\circ} \mathrm{C}$ and $0.22-0.39 \mathrm{mg} / \mathrm{m}^{3}$ during intermediate monsoon of October. These values corresponded with the environmental variables obtained from the highest fishing activities during each monsoon (Figure 2).

\section{DISCUSSION}

This study identified and explored the monsoonal fishing grounds of $R$. kanagurta in the SCS off east coast of Peninsular Malaysia by employing the actual fishing locations and satellite-based oceanographic data using MaxEnt habitat models. These data were utilized based on the hypothesis that particular areas where fishers operates have higher abundance of target species, and by quantifying them with environmental predictors, suitable habitats of the fish can be predicted (Alabia et al. 2015; Morris \& Ball 2006; Zwolinski et al. 2011). In the marine ecosystem, predictive models are adopted to study the relationship between the species and the environment build on the hypothesis that the species ideal habitats are determined by oceanographic biophysical processes

TABLE 2. Results of statistics derived from the models for the period of $2009.70 \%$ of the occurrence data were used for calibrating the base models while the remaining $30 \%$ of the data were used to calculate the values of AUC and standard deviation (SD). Meanwhile, $\mathrm{N}$ is the total number of fishing locations for each monsoon

\begin{tabular}{ccccc}
\hline Models & Months & $\mathrm{N}$ & AUC & SD \\
\hline Northeast & November-March & 449 & 0.82 & 0.02 \\
Intermediate & April & 277 & 0.92 & 0.02 \\
Southwest & May-September & 1483 & 0.92 & 0.01 \\
Intermediate & October & 156 & 0.86 & 0.03 \\
\hline
\end{tabular}




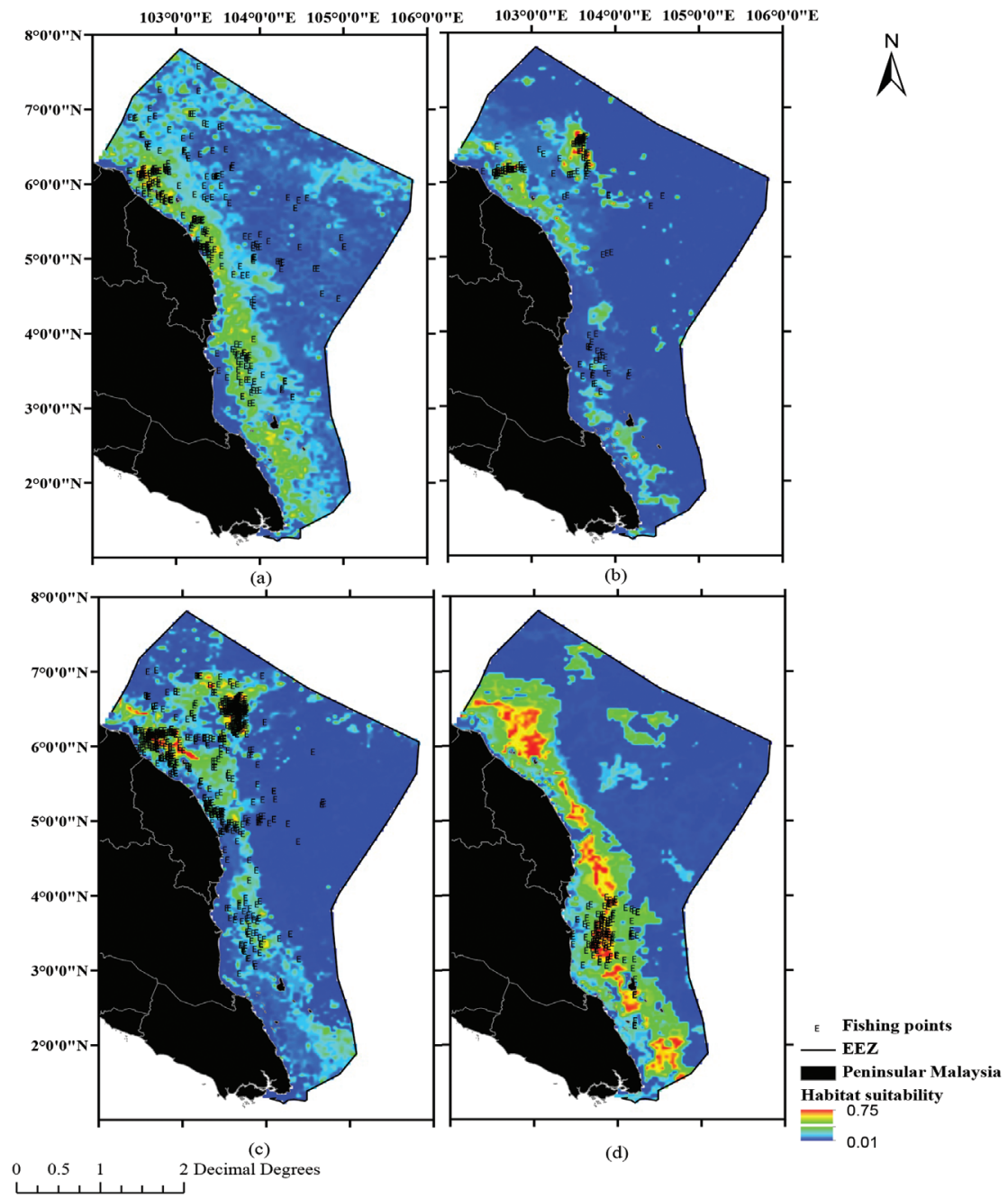

FIGURE 3. Habitat suitability maps for R. kanagurta in the EEZ during (a) northeast monsoon, (b) April, (c) southwest monsoon and (d) October of 2009, overlain with fishing points of $R$. kanagurta. Warmer colour indicates high suitability

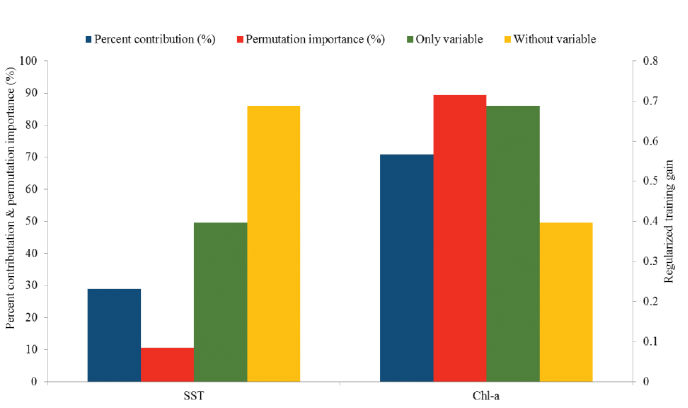

(a)

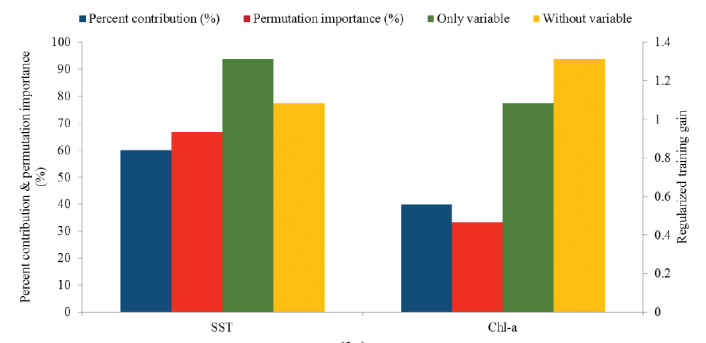

(b)

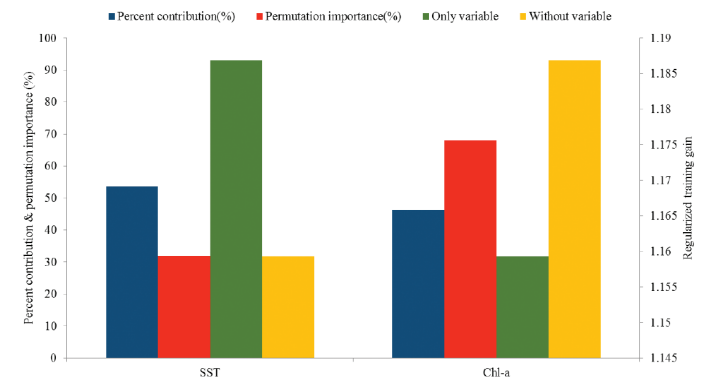

(c)

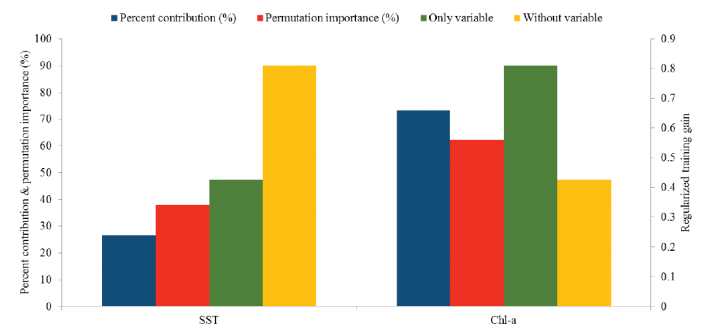

(d)

FIGURE 4. Variable importance derived from the seasonal model during (a) northeast monsoon,

(b) April, (c) southwest monsoon and (d) October of 2009 
(a)

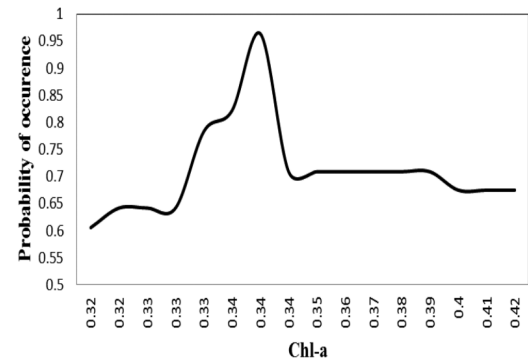

(b)

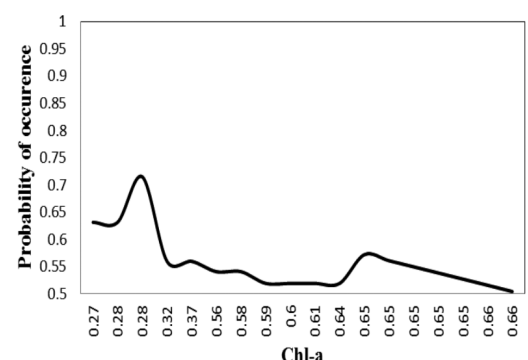

(c)

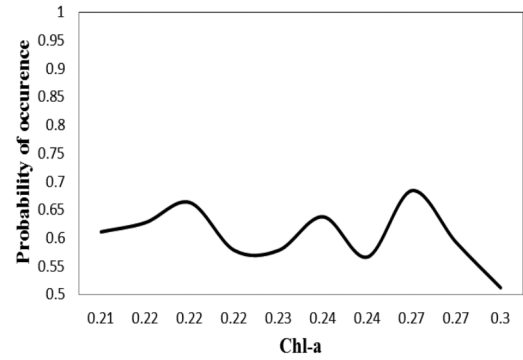

(d)

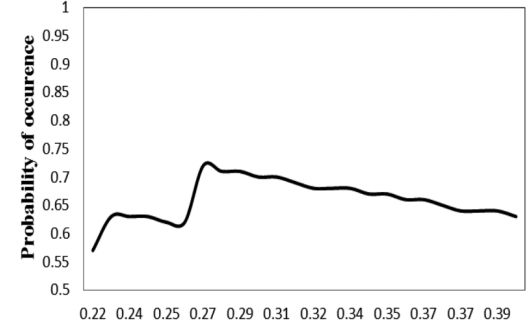

Chl-a
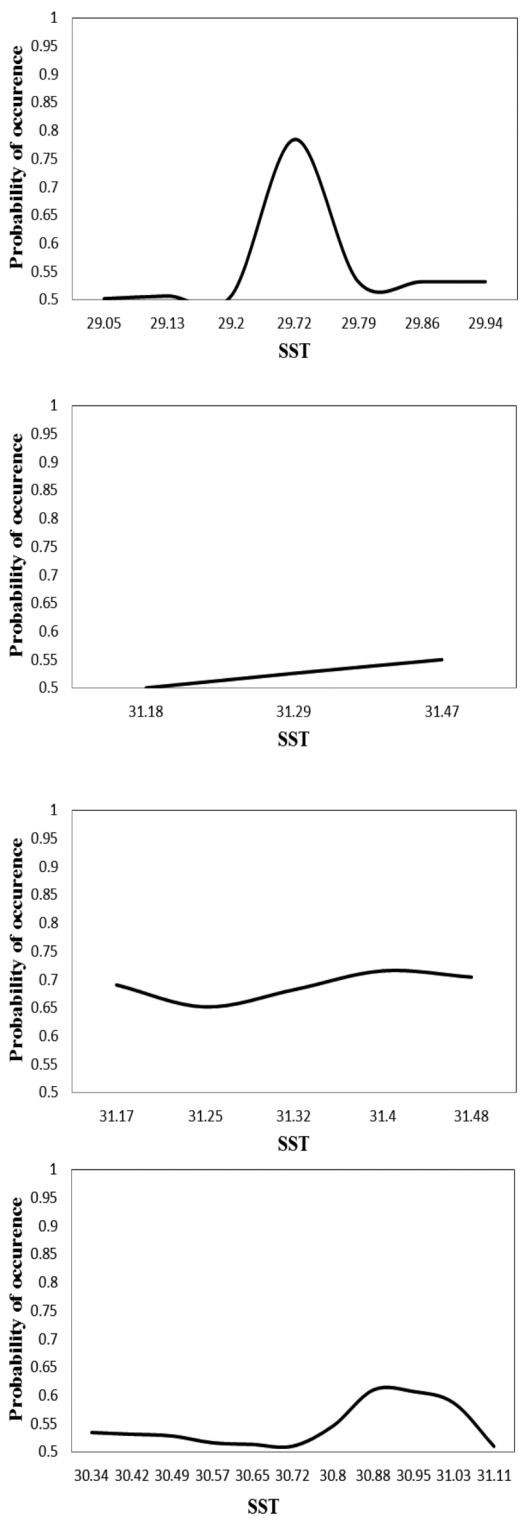

SST

FIGURE 5. Response curves of environmental variables, chl- $a$ (left panel) and SST (right panel) indicating probability of occurrence during (a) northeast monsoon, (b) April, (c) southwest monsoon and (d) October of 2009. Solid lines show the relationship between each variable and distribution of $R$. kanagurta

(Guisan \& Thuiller 2005; Guisan \& Zimmermann 2000; McKinney et al. 2012).

The MaxEnt algorithm employed in this study resulted in a good to excellent predictive ability in predicting seasonal potential fishing area at least in sites that were sufficiently sampled in the base models. AUC values higher than 0.80 indicated that the regional base models had a good agreement with the testing data (Table 2). It was observed that chl- $a$ concentration was the most important oceanographic factor influencing distribution during northeast and intermediate monsoon of October while during intermediate monsoon of April and southwest monsoon, SST contributed the most towards the distribution. The results indicated that seasonal oceanographic variables and changes in physical oceanography influenced the aggregation of $R$. kanagurta. The results also indicated that at presence probabilities of 0.5 fixed threshold, probability of potential fishing area can be observed spatially and temporally $\left(8832 \mathrm{~km}^{2}\right.$ during northeast, $3376 \mathrm{~km}^{2}$ in April, $2944 \mathrm{~km}^{2}$ during southwest monsoon and $13632 \mathrm{~km}^{2}$ in October). This suitable area indicated the potential of high catch production in this area.

During intermediate monsoon of October, as sea surface heating weakened and influence from river discharge near the coastal area, stratification layer at the surface of the ocean starts to dissolve. The surface temperature continued to decrease and sea surface wind started to increase (Figure 6(a)) until the start of northeast monsoon. Lower SST has been related to probability of upwelling occurrences at the coastal area. The upwelling process is mainly produced by Ekman transport which indicated the movement of deep, cold and high nutrient 
water mass to the surface (Bardiyanto \& Kasa 2012). The rich nutrient water contributed to the high chl- $a$ concentration. Chaturvedi and Narain (2003) found that chl- $a$ varied in the areas which are close to the coast, which is also proven by Amin et al. (2014). Apart from that, river discharge also contributed to the high chl- $a$ concentration and attracted fish aggregation. This was supported by the higher probability of suitable habitat observed along the coastal and offshore area. These suitable habitats were explained by SST of $30.34-31.11^{\circ} \mathrm{C}$ and chl- $a$ of $0.22-0.39 \mathrm{mg} / \mathrm{m}^{3}$.

Approaching northeast monsoon, the area is characterized by cooler and saltier water from the north of SCS which is influenced by southward current and driven by northeast monsoonal winds (Akhir \& Chuen 2011). The East Coast of Peninsular Malaysia also receives maximum precipitation in November and December. Krishnamurthy and Kinter (2002) suggested that the strong winds and high precipitation during the northeast monsoon contributed to the cooler SST. Figure 6(b) indicates lower SST and higher chl- $a$ concentration along the coast. Occurrence of high wind speed resulting from the strong northeasterly winds over SCS at the speed of $5-8 \mathrm{~ms}^{-1}$ was also observed during the northeast monsoon. Apart from that, southern and eastern coasts of Peninsular Malaysia experienced heavy rainfall due to the movement and direction of the winds. Total monthly rainfall during northeast monsoon in January and intermediate monsoon of October 2009 showed that the coastal area experienced maximum rainfall reaching $800 \mathrm{~mm}$ in January and 600 $\mathrm{mm}$ in October 2009 (Figure 7(a)). Average rainfall was observed to be above $200 \mathrm{~mm}$. High precipitation contributed to increased productivity and nutrient due to high discharge from the rivers (Shaari \& Mustapha 2017). High chl- $a$ concentration and low SST $\left(29.05-29.94^{\circ} \mathrm{C}\right.$ and $0.32-0.42 \mathrm{mg} / \mathrm{m}^{3}$, respectively) scattered along the coast was observed to be associated with the favourable conditions for fish as feeding grounds as indicated by the habitat suitability map during northeast monsoon (Figure 6(b)).

Meanwhile, during intermediate monsoon of April and southwest monsoon, increased in SST was observed and water is usually less saline and covered almost the entire east of Peninsular Malaysia. SST during April was higher because of weak southwest sea surface wind at a speed of 4-6 $\mathrm{ms}^{-1}$ (Figure 8(a)) suggesting contribution to the development of stratification (Akhir \& Chuen 2011; Yanagi et al. 2001). Figure 8(a) shows high SST and higher concentrations of chl- $a$ along the coastal area. Habitat suitability map indicated potential distribution along the coastal and offshore area associated with chl- $a$ and SST in the range of $0.27-0.66 \mathrm{mg} / \mathrm{m}^{3}$ and 31.29-31. $47^{\circ} \mathrm{C}$, respectively (Figure 8(a)). Approaching southwest monsoon Figure 8(b), higher SST was observed, mainly because of the weak sea surface wind especially at the northern part of the east coast. As a result, this monsoon also experienced less precipitation (Figure 7(b)) which was recorded below $200 \mathrm{~mm}$ and less river discharge resulting in lower chl- $a$ concentration. High SST and surface water salinity resulted from the lesser river discharge formed stratified water column (Shaari $\&$ Mustapha 2017). Lesser nutrient input resulted to the lower chl- $a$ concentration. This contributed to lower habitat suitable for fish distribution during this monsoon which was explained by chl-a of $0.21-0.30 \mathrm{mg} / \mathrm{m}^{3}$ and SST of $31.17-31.48^{\circ} \mathrm{C}$.

(a)

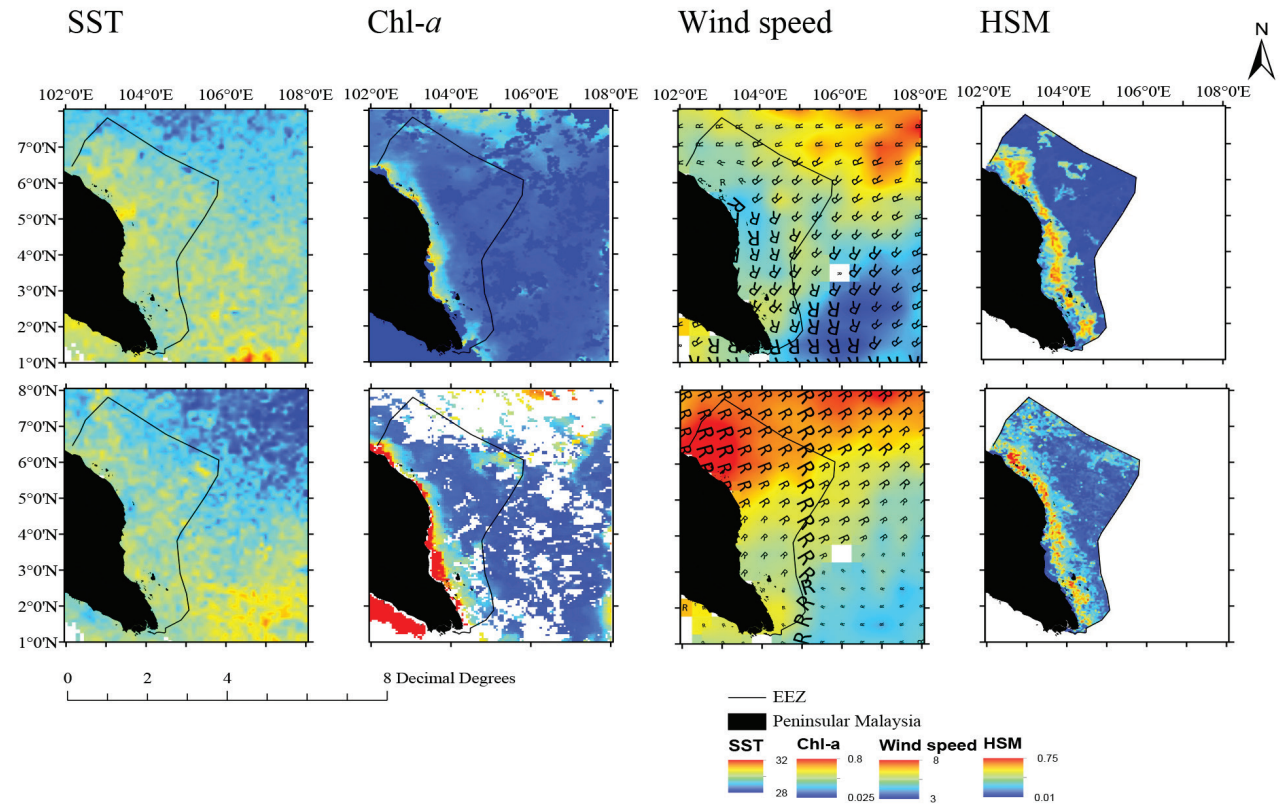

FIGURE 6. SST, chl- $a$, wind speed and habitat suitability map (HSM) during (a) October and (b) northeast monsoon in November 2009 


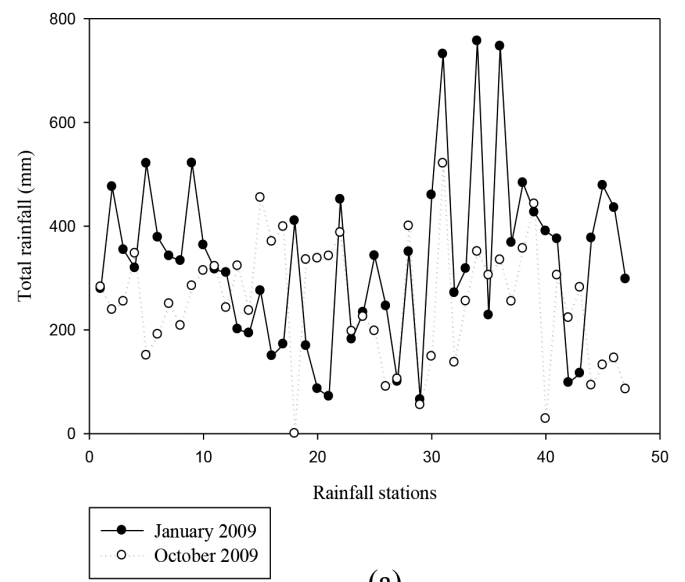

(a)

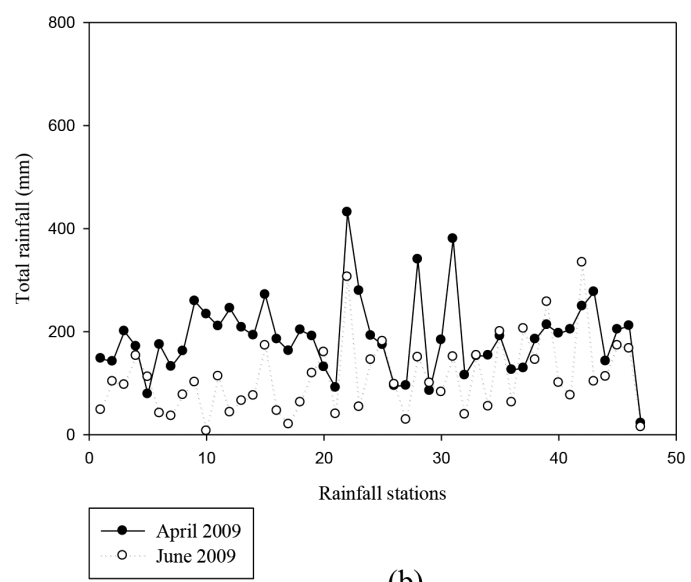

(b)

FIGURE 7. Total rainfall during northeast monsoon in January and intermediate monsoon of October (a) and intermediate monsoon in April and southwest monsoon in June (b) 2009

SST

(a)

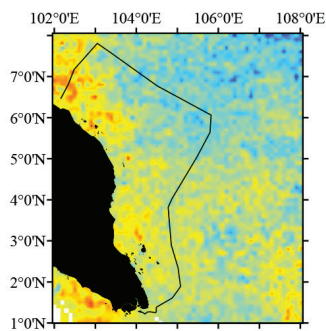

(b)
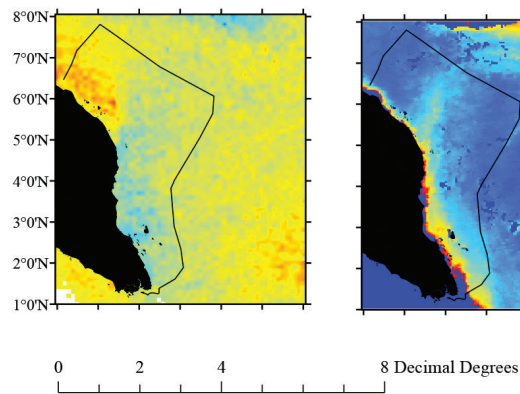

Wind speed HSM
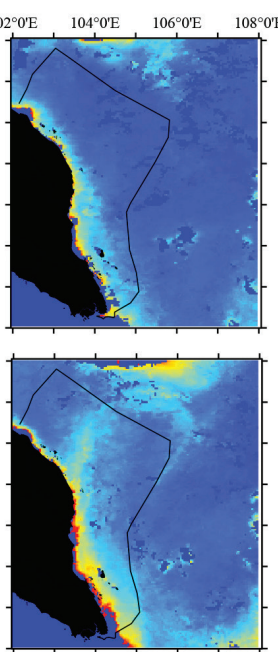

8 Decimal Degree
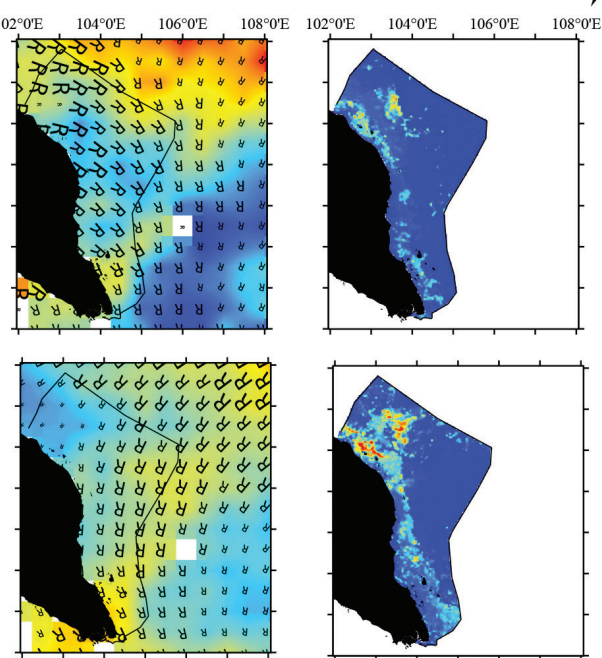

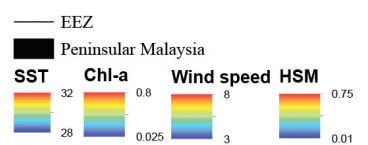

FIGURE 8. SST, chl- $a$, wind speed and habitat suitability map (HSM) during (a) April and (b) southwest monsoon in June 2009

\section{CONCLUSION}

This study showed that $R$. kanagurta's potential suitable habitats were influenced by seasonal and spatial oceanographic features during northeast, southwest and intermediate monsoons. This study also indicated the applicability of MaxEnt to determine seasonal potential fishing grounds and determine environmental factors that characterized the potential fishing grounds in the SCS off east coast Peninsular Malaysia. The models also strengthened the understanding that physical processes contributed to the formation of pelagic hotspots and accentuate changes in habitat conditions at different spatial and temporal scales. The integration of fishing data with remote sensing information in the study region within the model application could provide an inventive approach to identify the potential fishing zones for R. kanagurta and the information could be invaluable in marine spatial planning and fisheries management. Besides, the geographic prediction could be useful as a basis for protection of coastal biodiversity as the habitat suitability maps result in targeted geographical locations and subsequently, costefficient monitoring programme. 


\section{ACKNOWLEDGEMENTS}

The authors would like to thank SEAFDEC for the fisheries data. Gratitude is also conveyed to Distributed Active Archive Centre at the NASA Goddard Space Flight Centre for the production and distribution of the MODIS data. The authors also gratefully acknowledge UKM for the research facilities and valuable technical assistance provided.

\section{REFERENCES}

Akhir, M.F. \& Chuen, Y.J. 2011. Seasonal variation of water characteristics during inter-monsoon along the East Coast of Johor. Journal of Sustainability Science and Management 6: 206-214.

Alabia, I.D., Saitoh, S-I., Mugo, R., Igarashi, H., Ishikawa, Y., Usui, N., Kamachi, M., Awaji, T. \& Seito, M. 2015. Seasonal potential fishing ground prediction of neon flying squid (Ommastrephes bartramii) in the western and central North Pacific. Fisheries Oceanography 24: 190-203.

Amin, M.A.R., Ahmad, M.F., Hussim, M.H., Embong, M.F. \& Draman, R. 2014. Chlorophyll- $a$ concentration variation over Terengganu maritime. International Journal of Innovative, Science, Engineering \& Technology 1: 406-410.

Bardiyanto. \& Kasa, W. 2012. Studi penangkapan ikan kembung (Rastrelliger kanagurta) dengan menggunakan data satelit di Laut Jawa pada musim tenggara dan barat laut. Ecotrophic 5: 21-26.

Chassot, E., Bonhommeau, S., Reygondeau, G., Nieto, K., Polovina, J.J., Huret, M., Dulvy, N.K. \& Demarcq, H. 2011. Satellite remote sensing for an ecosystem approach to fisheries management. ICES Journal of Marine Science 68: 651-666.

Chaturvedi, N. \& Narain, A. 2003. Chlorophyll distribution pattern in the Arabian Sea: Seasonal and regional variability, as observed from SeaWiFS data. International Journal of Remote Sensing 24: 511-518.

Duan, R.Y., Kong, X.Q., Huang, M.Y., Fan, W.Y. \& Wang, Z.G. 2014. The predictive performance and stability of six species distribution models. PLOS ONE 9: e112764.

Elith, J., Graham, C.H., Anderson, R.P., Dudik, M., Ferrier, S. \& Guisan, A. 2006. Novel methods improve prediction of species' distributions from occurrence data. Ecography 29: 129-151.

Gu, W. \& Swihart, R.K. 2004. Absent or undetected? Effects of non-detection of species occurrence on wildlife-habitat models. Biology of Conservation 116: 195-203.

Guisan, A. \& Zimmermann, N.E. 2000. Predictive habitat distribution models in ecology. Ecological Modelling 135: 147-186.

Guisan, A. \& Thuiller, W. 2005. Predicting species distribution: Offering more than simple habitat models. Ecological Letter 8: 993-1009.

Hernandez, P.A., Graham, C.H., Master, L.L. \& Albert, D.L. 2006. The effects of sample size and species characteristics on performance of different species distribution modeling methods. Ecography 29: 773-785.

Krishnakumar, P.K., Mohamed, K.S., Asokan, P.K., Sathianandan, T.V., Zacharia, P.U., Abdurahiman, K.P., Shettigar, V. \& Durgekar, R.N. 2008. How environmental parameters influenced fluctuations in oil sardine and mackerel fishery during 1926-2005 along the South-West Coast of India? Marine Fisheries Information Service Technical and Extension Series 198: 1-5.
Krishnamurthy, V. \& Kinter, J.L.III. 2002. The Indian monsoon and its relation to global climate variability. In Global Climate, edited by Rodo, X. New York: Springer-Verlag.

Lanz, E., Nevarez-Martinez, M., López-Martinez, J. \& Dworak, J.A. 2009. Small pelagic fish catches in the Gulf of California associated with sea surface temperature and clorophyll. CalCOFI Report 50: 134-146.

Mackenzie, D.K., Nichols, J.D., Lachman, G.B., Droege, S., Royle, J.A. \& Langtimm, C.A. 2002. Estimating site occupancy rates when detection probabilities are less than one. Ecology 83: 2248-2255.

Manderson, J., Palamara, L., Kohut, J. \& Oliver, M. 2011. Ocean observatory data are useful for regional habitat modelling of species with different vertical habitat preferences. Marine Ecology Progress Series 438: 1-7.

McKinney, M.A., McMeans, B.C., Tomy, G.T., Rosenberg, B. \& Ferguson, S.H. 2012. Trophic transfer of contaminants in a changing arctic marine food web: Cumberland Sound, Nunavut, Canada. Environmental Science and Technology 46: 9914-9922.

Malaysian Meteorological Department (MMD). 2017. Malaysia's climate. http://www.met.gov.my/web/metmalaysia/climate/ generalinformation/malaysia. Accessed on 19 September 2017.

Morris, L. \& Ball, D. 2006. Habitat suitability modelling of economically important fish species with commercial fisheries data. ICES Journal of Marine Science 63: 15901603.

Mustapha, M.A., Shaari, N., Lihan, T., Razib, N.A., Raja Bidin Raja Hassan, Y.M. \& Yaacob, K.K.K. 2014. Characterizing potential fishing area of Rastrelliger kanagurta in the exclusive economic zone (EEZ) of Malaysia using remotely sensed oceanographic data. Ecology, Environment and Conservation 20: 15-20.

Muthoni, F.K. 2010. Modelling the spatial distribution of snake species under changing climate scenario in Spain. Tesis S. Sn. Faculty of Geo-information Science and Earth Observation, University of Twente (Unpublished).

Nammalwar, P., Satheesh, S. \& Ramesh, R. 2013. Applications of remote sensing in the validations of potential fishing zones (PFZ) along the Coast of North Tamil Nadu, India. Indian Journal of Geo-Marine Sciences 42: 283-292.

Nurdin, S., Mustapha, M.A., Lihan, T. \& Abd Ghaffar, M. 2015. Determination of potential fishing grounds of Rastrelliger kanagurta using satellite remote sensing and GIS technique. Sains Malaysiana 44(2): 225-232.

O'Reilly, J.E., Maritorena, S., Mitchell, B.G., Siegel, D.A., Carder, K.L., Garver, S.A., Kahru, M. \& McClain, C. 1998. Ocean color clorophyll algorithm for SEaWiFS. Journal of Geophysical Research 103: 24937-24954.

Phillips, S.J., Anderson, R.P. \& Schapire, R.E. 2006. Maximum entropy modeling of species geographic distributions. Ecological Modelling 190: 231-259.

Phillips, S.J. \& Dudik, M. 2008. Modeling of species distributions with MaxEnt: New extensions and a comprehensive evaluation. Ecography 31: 161-175.

Reddy, M.T., Begum, H., Sunil, N., Pandravada, S.R., Sivaraj, N. \& Kumar, S. 2015. Mapping the climate suitability using MaxEnt modeling approach for Ceylon Spinach (Basella alba L.) cultivation in India. The Journal of Agricultural Sciences 10: 87-97.

Rijnsdorp, A.D., Peck, M.A., Engelhard, G.H., Möllmann, C. \& Pinnegar, J.K. 2009. Resolving the effect of climate change 
on fish populations. ICES Journal of Marine Science 66: 1570-1583.

Shaari, F. \& Mustapha, M.A. 2017. Factors influencing the distribution of chl- $a$ along coastal waters of east Peninsular Malaysia. Sains Malaysiana 46(8): 1191-1200.

Solanki, H.U., Dwivedi, R.M., Nayak, S.R., Jadeja, J.V., Thakar, D.B., Dave, H.B. \& Patel, M.I. 2001. Application of ocean color monitor chlorophyll and AVHRR SST for fishery forecast: Preliminary validation results off Gujarat Coast, Northwest Coast of India. Indian Journal of Marine Science 30: $132-138$.

Syah, A.F., Saitoh, S-I., Alabia, I.D. \& Hirawake, T. 2016. Predicting potential fishing zones for Pacific saury (Cololabis saira) with maximum entropy models and remotely sensed data. Fishery Bulletin 114(3): 330-342.

Tobeña, M., Prieto, R., Machete, M. \& Silva, M.A. 2016. Modeling the potential distribution and richness of Cetaceans in the Azores from Fisheries Observer Program Data. Frontiers in Marine Science 3: 202.

Vivekanandan, E., Gomathy, S., Thirumilu, P., Meiyappan, M.M. \& Balakumar, S.K. 2009. Trophic level of fishes occurring along the Indian Coast. Journal of Marine Biological Association of India 51(1): 44-51.

Yanagi, T., Sachoemar, S., Takao, T. \& Fujiwara, S. 2001. Seasonal variation of stratification in the Gulf of Thailand. Journal of Oceanography 57(4): 461-470.
Zainuddin, M. \& Saitoh, S. 2004. Detection of potential fishing ground for albacore tuna using synoptic measurements of ocean color and thermal remote sensing in the northwestern North Pacific. Geophysical Research Letters 31: L20311.

Zwolinski, J.P., Emmet, R.L. \& Demer, D.A. 2011. Predicting habitat to optimize sampling of Pacific sardine (Sardinops sagax). ICES Journal of Marine Science 68: 867-879.

School of Environmental and Natural Resources Sciences Faculty of Science and Technology

Universiti Kebangsaan Malaysia 43600 UKM Bangi, Selangor Darul Ehsan

Malaysia

Institute of Climate Change

Universiti Kebangsaan Malaysia

43600 UKM Bangi, Selangor Darul Ehsan Malaysia

*Corresponding author; email: muzz@ukm.edu.my

Received: 9 March 2018

Accepted: 14 September 2018 